\title{
Species- and substrate-specific stimulation of human plasma paraoxonase 1 (PON1) activity by high chloride concentration
}

\author{
Jerzy Bełtowski ${ }^{\bowtie}$, Grażyna Wójcicka and Andrzej Marciniak \\ Department of Pathophysiology, Medical University, Lublin, Poland
}

Received: 28 May, 2002; revised: 28 October, 2002; accepted: 21 November, 2002

Key words: paraoxonase, arylesterase, lipid peroxidation, oxidative stress

\begin{abstract}
Paraoxonase 1 (PON1), contained in plasma high-density lipoproteins, plays an important role in the protection of plasma lipoproteins and cell membranes from oxidative damage. Previous studies indicate that human PON1 is stimulated by high $\mathrm{NaCl}$ concentrations. The aim of this study was to characterize in more detail the effect of salts on serum PON1. Paraoxon-hydrolyzing activity of human serum was stimulated by $81.6 \%$ following the addition of $1 \mathrm{M} \mathrm{NaCl}$. The effect of $\mathrm{NaCl}$ was dose-dependent between 0.5 and $2 \mathrm{M}$. PON1 activity toward phenyl acetate was reduced by $1 \mathrm{M} \mathrm{NaCl}$ by $55.2 \%$. Both the paraoxon- and phenyl acetate-hydrolysing activity was slightly lower in heparinized plasma than in serum, but $\mathrm{NaCl}$ had similar stimulatory and inhibitory effects on these activities, respectively. In rat, rabbit, and mouse, $\mathrm{NaCl}$ reduced PON1 activity. $\mathrm{KCl}$ had a similar effect on human PON1 as NaCl. Sodium nitrite also stimulated human PON1 but much less effectively than chloride salts. In contrast, sucrose, sodium acetate and sodium lactate had no significant effect. $\mathrm{NaBr}$ was a less effective PON1 activator than $\mathrm{NaCl}$, whereas the effect of $\mathrm{NaJ}$ was non-significant. The activity of human PON1 toward homogentisic acid lactone and $\gamma$-decanolactone was unaltered by $\mathrm{NaCl}$. These data indicate that: 1) high concentrations of chlorides stimulate human PON1 activity toward paraoxon but not other substrates, 2) PON1 is inhibited by $\mathrm{Cl}^{-}$in other mammalian species, 3) the potency of human PON1 activation by halogene salts increases with decreasing atomic mass of the halide anion.
\end{abstract}

Paraoxonase 1 (PON1) is a calcium-dependent "A-esterase" contained in plasma high-density lipoproteins (HDL), which hydrolyzes toxic acetylcholinesterase-inhibiting organic phosphates, such as paraoxon (La Du et al., 1993; Mackness et al., 1996). Studies performed during the last 10 years indicate that PON1 has multiple other important functions. PON1 protects low-density lipoproteins from oxidative modification by reactive oxygen spe-

\footnotetext{
This study was supported by grant PW 447/2002 from the Medical University, Lublin, Poland.

${ }$ Jerzy Bełtowski, Department of Pathophysiology, Medical University, Jaczewskiego 8, 20-090 Lublin, Poland; tel: (48 81) 742 5837; fax: (48 81) 742 5828; e-mail: patfiz@asklepios.am.lublin.pl Abbreviations: AE, arylesterase; HDL, high-density lipoproteins; PON1, paraoxonase 1.
} 
cies and thus significantly contributes to the atheroprotective effect of HDL (Mackness et al., 1991; Mackness et al., 1993; Watson et al., 1995). The enzyme also hydrolyzes phospholipid hydroperoxides and cholesterol ester hydroperoxides (esterase activity) and reduces lipid hydroperoxides to the respective hydroxides as well as degrades hydrogen peroxide (peroxidase activity) (Aviram et al., 2000). PON1 also protects HDL from peroxidation and improves reverse cholesterol transport to the liver (Aviram et al., 1998b). It is also suggested that PON1 protects plasma membranes from free radical injury (Durrington et al., 2001). The enzyme degrades bioactive phospholipids, such as platelet-activating factor (PAF) (Rodrigo et al., 2001). Recent studies indicate that PON1 possesses lactonase activity and is involved in the metabolism of some drugs such as statins, spironolactone and glucocorticoid lactones (Billecke et al., 2000). Finally, it hydrolyzes homocysteine thiolactone and prevents protein homocysteinylation, a process involved in atherogenesis (Jakubowski, 2000). Two closely related proteins: PON2 and PON3 have been identified. PON3 is also contained in HDL particles (Draganov et al., 2000; Reddy et al., 2001) whereas PON2 is absent in plasma but is expressed in many tissues $(\mathrm{Ng}$ et al., 2001). Both PON2 and PON3 possess antioxidant properties and lactonase activity, but unlike PON1, they lack the paraoxon- or phenyl acetate-hydrolyzing activity.

Early studies indicated that the paraoxonbut not phenyl acetate-hydrolyzing activity of human plasma PON1 is activated by high concentration of $\mathrm{NaCl}$ (Eckerson et al., 1983a; 1983b). However, neither the effect of other salts nor the mechanism of this stimulation have been investigated. Recent data indicate that basal and NaCl-stimulated PON1 activity may be differentially regulated under pathologic conditions, which suggests a possible physiologic and diagnostic significance of PON1 measurement in the presence of $\mathrm{NaCl}$ (Schiavon et al., 1996).
The purpose of this study was to examine more extensively PON1 stimulation by $\mathrm{NaCl}$. We investigated this effect in different mammalian species, compared the effect of different salts and evaluated the effect of $\mathrm{NaCl}$ on other PON1 activities, such as arylesterase and lactonase activity.

\section{MATERIALS AND METHODS}

Sample collection. Blood was obtained from 15 male healthy volunteers at the age of 28-54 years without any chronic diseases and taking no medications. Neither of them suffered from acute infection during 4 weeks before the study and neither had a history of atherosclerosis risk factors known to affect PON1 activity (diabetes mellitus, hyperlipidemia, smoking, arterial hypertension). Blood was withdrawn by venipuncture after overnight fasting. All persons were normolipidemic (plasma cholesterol and triglycerides $<200 \mathrm{mg} / \mathrm{dl}$ ), normoglycemic (glucose $<100 \mathrm{mg} / \mathrm{dl})$ and normotensive $(\mathrm{RR}<140 / 90$ $\mathrm{mmHg}$ ) at the time of the study.

Animal studies were performed on adult male Wistar rats, white New Zealand rabbits and Swiss mice ( $\mathrm{n}=10$ for each species). Blood was obtained from the rats from the abdominal aorta under pentobarbital anaesthesia (50 mg/kg i.p.). In rabbits, blood samples were withdrawn from the ear vein. From mice blood was collected after decapitation.

Blood samples were collected to glass tubes, allowed to clot for $1 \mathrm{~h}$ at room temperature and was centrifuged for $10 \mathrm{~min}$ at $3000 \times \boldsymbol{g}$ at $4^{\circ} \mathrm{C}$. Serum was separated, frozen and stored at $-25^{\circ} \mathrm{C}$ until assay. Separate samples were withdrawn into heparinized tubes (for PON1 assay in plasma) and into EDTA-containing tubes (for plasma lipid profile and glucose).

The study protocol was reviewed and approved by the local ethics committee.

Measurement of PON1 activity. PON1 activity toward paraoxon (diethyl-p-nitrophenyl phosphate) was determined by mea- 
suring the initial rate of substrate hydrolysis to $p$-nitrophenol, whose absorbance was monitored at $412 \mathrm{~nm}$ in the assay mixture $(800 \mu \mathrm{l})$ containing $2.0 \mathrm{mM}$ paraoxon, $2.0 \mathrm{mM} \mathrm{CaCl}_{2}$ and $20 \mu \mathrm{l}$ of serum or plasma in $100 \mathrm{mM}$ Tris/HCl buffer ( $\mathrm{pH}$ 8.0). A blank sample containing incubation mixture without plasma was run simultaneously to correct for spontaneous substrate breakdown. The enzyme activity was calculated from $\varepsilon_{412}$ of p-nitrophenol $\left(18290 \mathrm{M}^{-1} \cdot \mathrm{cm}^{-1}\right)$ and was expressed in $\mathrm{U} / \mathrm{ml} ; 1 \mathrm{U}$ of enzyme hydrolyzes $1 \mathrm{nmol}$ of paraoxon/ min (Schiavon et al., 1996; Ayub et al., 1999).

The activity toward phenyl acetate (arylesterase activity) was determined by measuring the initial rate of substrate hydrolysis in the assay mixture $(3 \mathrm{ml})$ containing $2 \mathrm{mM}$ substrate, $2 \mathrm{mM} \mathrm{CaCl} 2$ and $10 \mu \mathrm{l}$ of serum or plasma in $100 \mathrm{mM}$ Tris/ $\mathrm{HCl}(\mathrm{pH}$ 8.0). The absorbance was monitored for $3 \mathrm{~min}$ at 270 nm. Blank sample prepared as described above but without plasma, representing nonenzymatic hydrolysis, was subtracted and the activity was calculated from $\varepsilon_{270}=1310$ $\mathrm{M}^{-1} \cdot \mathrm{cm}^{-1}$. The results are expressed in $\mathrm{U} / \mathrm{ml}, 1 \mathrm{U}$ of arylesterase hydrolyzes $1 \mu \mathrm{mol}$ of phenyl acetate per minute (Schiavon et al., 1996, Ayub et al., 1999).

PON1 is also able to hydrolyze aromatic and aliphatic lactones. We assayed the activity toward homogentisic acid lactone and $\gamma$-decanolactone representing these two groups, respectively, because these compounds are vigorously metabolized by PON1, and other PONs have little contribution to their hydrolysis by serum (Reddy et al., 2001). The activity toward homogentisic acid lactone was assayed in $50 \mathrm{mM}$ Tris/ $\mathrm{HCl}(\mathrm{pH}$ 8.0) containing $1 \mathrm{mM} \mathrm{CaCl}_{2}$ and $1 \mathrm{mM}$ substrate (from $100 \mathrm{mM}$ stock solution in methanol). The absorbance at $290 \mathrm{~nm}$ was monitored and the rate of hydrolysis was calculated from the difference between the absorption coefficients of the acid formed and the lactone (816
$\mathrm{M}^{-1} \cdot \mathrm{cm}^{-1}$ ) (Draganov et al., 2000; Billecke et $a l ., 2000)$.

The hydrolysis of $\gamma$-decanolactone was measured in $2 \mathrm{mM}$ Hepes buffer ( $\mathrm{pH}$ 8.0) containing $1 \mathrm{mM} \mathrm{CaCl} 2,0.004 \%$ phenol red, $0.005 \%$ bovine serum albumin and $1 \mathrm{mM}$ substrate (from $100 \mathrm{mM}$ stock solution in methanol). The increase in absorbance was monitored at $422 \mathrm{~nm}$ after addition of sample and the rate of hydrolysis was calculated from the calibration curve obtained using known amounts of $\mathrm{HCl}$. The activity was expressed in moles of acid produced by $1 \mathrm{ml}$ of serum in $1 \mathrm{~min}$ (Billecke et al., 2000).

All measurements were performed at $25^{\circ} \mathrm{C}$. The effect of salts on PON1 activity was assayed in the respective buffers containing additionally the investigated salt at the appropriate concentration. These buffers were prepared separately and their $\mathrm{pH}$ was always adjusted to 8.0.

Paraoxon, phenyl acetate, homogentisic acid lactone, $\gamma$-decanolactone, phenol red, bovine serum albumin, Tris and HEPES were obtained from Sigma-Aldrich. All other reagents were of research grade. Plasma cholesterol, triglycerides and glucose were assayed using Sigma-Aldrich kits.

Because due to genetic polymorphism human serum paraoxonase activity demonstrates trimodal distribution, statistical analyses were performed by nonparametric Wilcoxon's test. The relationship between variables was analyzed by Spearman rank correlation test. $P<0.05$ was considered significant. Data in the text are reported as median (range).

The degree of homology of PON1 in different mammalian species was calculated on the basis of amino-acid sequences of the human, rat, rabbit and mouse enzymes obtained from the SWISS-PROT protein sequence database on the Expert Protein Analysis System (ExPASy) Molecular Biology Server (www.expasy.org). 


\section{RESULTS}

\section{The effect of $\mathrm{NaCl}$ on human PON1}

The paraoxon-hydrolyzing activity of human serum differed markedly between individuals, consistently with other studies indicating that a common genetic PON1 polymorphism (arginine or glutamine at position 192) affects the enzyme activity toward paraoxon (Eckerson et al., 1983a; Aviram et al., 1998a). Within the study group, the activity toward paraoxon ranged from 25.2 to $236.7 \mathrm{U} / \mathrm{ml}$ (median: $68.5 \mathrm{U} / \mathrm{ml}$ ). In all individuals $1 \mathrm{M}$ $\mathrm{NaCl}$ caused marked stimulation of the paraoxon hydrolyzing activity. The PON1 activity in the presence of $\mathrm{NaCl}$ was 49.9-462.6 $\mathrm{U} / \mathrm{ml}$ (median: $127.4 \mathrm{U} / \mathrm{ml}$ ), i.e. $41.0-169.9 \%$ (median: 81.6\%) higher than in the absence of this salt (Fig. 1). The PON1 activity toward paraoxon measured in heparinized plasma was by $3.7-19.4 \%$ (median $12.2 \%$ ) lower than in serum (Fig. 1). After addition of $1 \mathrm{M} \mathrm{NaCl}$, the plasma PON1 activity increased to 23.7-236.6 U/ml (median $52.7 \mathrm{U} / \mathrm{ml}$ ), i.e. by

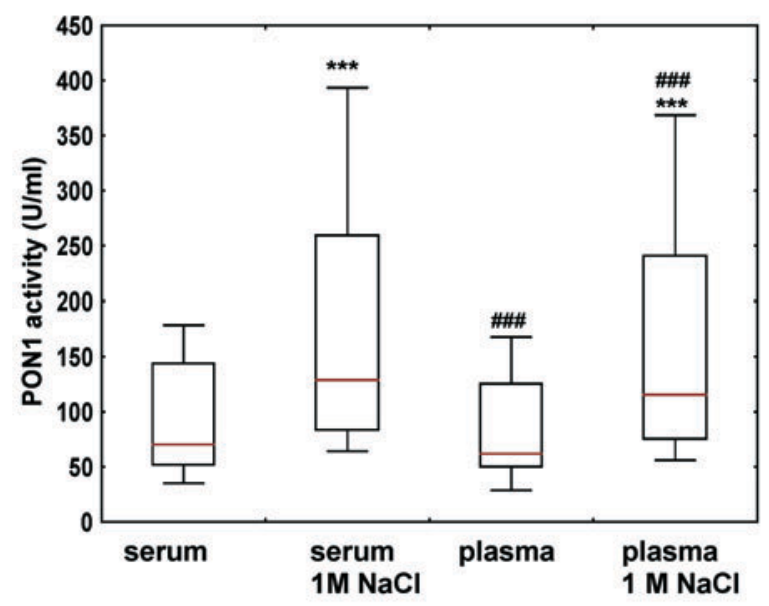

Figure 1. Box and whiskers plot of human PON1 activity toward paraoxon in serum and plasma in the absence and in the presence of $1 \mathrm{M} \mathrm{NaCl}$.

Boxes indicate median, 25 and 75 percentiles and whiskers represent 10 and 90 percentile. ${ }^{* * *} P<0.001$ (compared to the activity measured without $\mathrm{NaCl}$ ); ${ }^{\# \# \#} P<0.001$ (compared to the activity in serum) by nonparametric Wilcoxon test.
45.2-140.6\% (median 92.8\%). However, the $\mathrm{NaCl}$-stimulated activity in the plasma was 6.3-14.3\% (median 8.6\%) lower than the $\mathrm{NaCl}$-stimulated activity in the serum (Fig. 1). A very strong correlation between the PON1 activity in serum and plasma was observed both in the absence $(\mathrm{r}=0.995, P<0.001)$ and in the presence $(r=0.996, P<0.001)$ of $\mathrm{NaCl}$. In contrast to heparinized plasma and consistently with the $\mathrm{Ca}^{2+}$-dependence of PON1, very low activity was detected in plasma obtained using EDTA as an anticoagulant.

The absolute (expressed in $\mathrm{U} / \mathrm{ml}$ ) increase in PON1 activity after addition of salt correlated significantly with the basal unstimulated activity ( $\mathrm{r}=0.84, P<0.001)$.

The effect of $\mathrm{NaCl}$ on the paraoxon-hydrolysing activity was dose-dependent (Fig. 2).

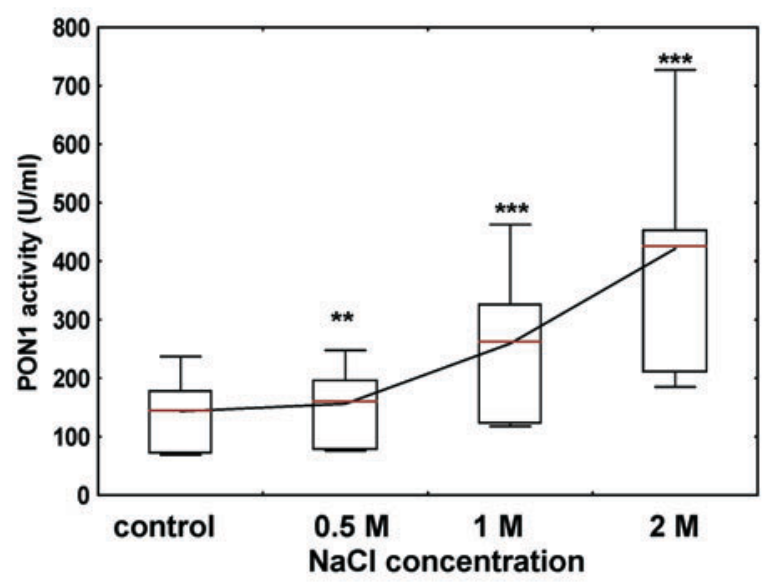

Figure 2. Dose-dependent effect of $\mathrm{NaCl}$ on human serum PON1 activity toward paraoxon.

${ }^{* *} P<0.01,{ }^{* * *} P<0.001$ (compared to control by nonparametric Wilcoxon's test).

$\mathrm{NaCl}$ at a concentration of $0.5 \mathrm{M}$ stimulated the enzyme by $4.6-11.0 \%$ (median $9.6 \%$ ), whereas $2 \mathrm{M}$ concentration increased its activity by $154.0-207.0 \%$ (median $194.2 \%$ ).

The PON1 activity toward phenyl acetate (arylesterase activity, AE) was much less variable in the study group (median: $171.9 \mathrm{U} / \mathrm{ml}$, range: $127-207.2 \mathrm{U} / \mathrm{ml}$ ) consistently with the fact that this activity is not affected by the genetic polymorphism. Addition of $1 \mathrm{M} \mathrm{NaCl}$ to 
the assay mixture markedly reduced the $\mathrm{AE}$ activity $26.0-114.4 \mathrm{U} / \mathrm{ml}$ (median $77.6 \mathrm{U} / \mathrm{ml}$ ), i.e. to $20.5-57.9 \%$ (median $55.2 \%$ ) (Fig. 3). As in the case of paraoxon, the phenyl acetate-hydrolyzing activity of heparinized plasma was by $3.8-19.4 \%$ (median $12.8 \%$ ) lower in comparison to serum. $\mathrm{NaCl}$ reduced

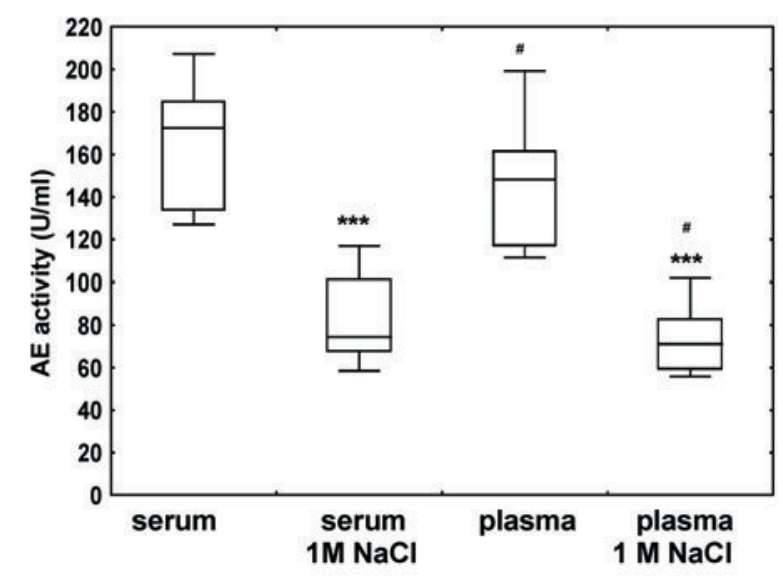

Figure 3. Human PON1 activity toward phenyl acetate (arylesterase activity, AE) in serum and plasma in the absence and in the presence of $1 \mathrm{M}$ $\mathrm{NaCl}$.

${ }^{* * *} P<0.001$ (compared to the activity measured without $\mathrm{NaCl}$ ); ${ }^{\#} P<0.05$ (compared to the activity in serum) by nonparametric Wilcoxon's test.

the $\mathrm{AE}$ activity in the plasma by $25.9-62.5 \%$ (median 51.9\%). The AE activity in the plasma correlated significantly with the $\mathrm{AE}$ activity in serum both in the absence $(\mathrm{r}=0.89, P=0.007)$ and in the presence $(\mathrm{r}=0.83, P=0.009)$ of $\mathrm{NaCl}$. Very low AE activity was noticed in EDTA plasma.

\section{The effect of $\mathrm{NaCl}$ on PON1 in animals}

The above results indicate that high concentration of $\mathrm{NaCl}$ stimulates only the paraoxonbut not the phenyl acetate-hydrolyzing activity of human PON1. To test whether this effect appears also in other mammalian species, we investigated the effect of $\mathrm{NaCl}$ on the rat, rabbit, and murine enzyme (Fig. 4). In contrast to human serum, $1 \mathrm{M} \mathrm{NaCl}$ reduced the PON1 activity in rat serum by $7.9-26.9 \%$ (me-

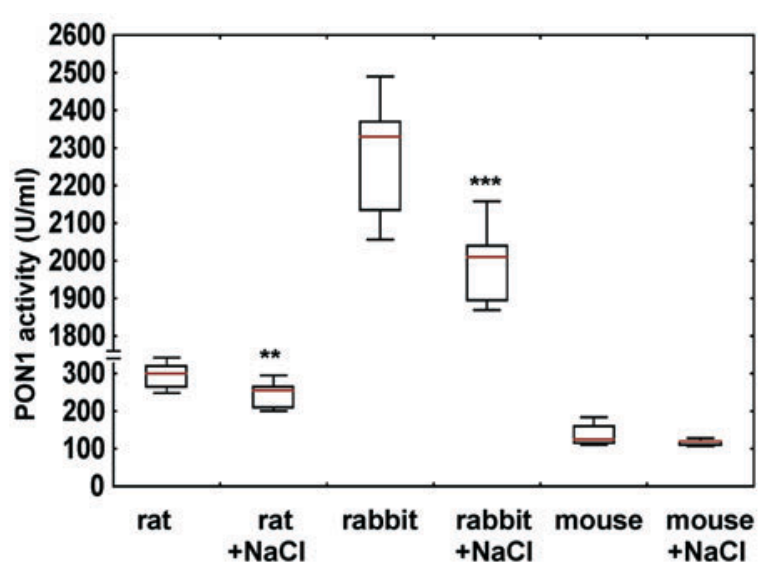

Figure 4. The effect of $1 \mathrm{M} \mathrm{NaCl}$ on paraoxon-hydrolyzing activity of serum from different mammalian species.

${ }^{* *} P<0.01,{ }^{* * *} P<0.001$ (compared to the activity measured without $\mathrm{NaCl}$ by nonparametric Wilcoxon's test).

dian $16.1 \%)$. The enzyme activity in rat heparinized plasma was $3.8-19.5 \%$ (median $12.8 \%$ ) lower than in the serum and was further inhibited following the addition of $\mathrm{NaCl}$ to the assay mixture by $6.3-14.3 \%$ (median $7.6 \%$ ). The $\mathrm{AE}$ activity in rat serum was lowered by $\mathrm{NaCl}$ from $142.6(108.3-156.1 \mathrm{U} / \mathrm{ml})$ to 51.7 (42.1-63.4 U/ml), i.e. by $55.5-66.8 \%$ (median $62.3 \%, P<0.001)$. Rat heparinized plasma demonstrated lower $\mathrm{AE}$ activity than serum (median: $134.1 \mathrm{U} / \mathrm{ml}$, range: 92.8-141.7 $\mathrm{U} / \mathrm{ml}, P<0.05$ ) and this was further decreased following the addition of $1 \mathrm{M} \mathrm{NaCl}$ to $43.8(32.1-57.9 \mathrm{U} / \mathrm{ml}, P<0.001$ vs the activity in the plasma without $\mathrm{NaCl}, P<0.05$ vs the activity in the serum with $\mathrm{NaCl}$ ).

Interestingly, a very high PON1 activity toward paraoxon was noticed in the rabbit serum (Fig. 4). The activity assayed in the presence of $\mathrm{NaCl}$ was $16.1-54.4 \%$ (median $22.3 \%$ ) lower than in the absence of this salt. In the mouse serum, $\mathrm{NaCl}$ decreased the enzyme activity in 9 of the 10 animals studied (maximally by $37.4 \%$ ), in one animal a slight $2.4 \%$ stimulation of the activity was observed. When all ten samples were taken into account, the median NaCl-induced change in the paraoxon-hydrolyzing activity was $-7.6 \%$ and 
was close to, but did not reach the level of significance $(P=0.06)$. Thus in all the animal species studied, $\mathrm{NaCl}$ reduced or tended to reduce PON1 activity, although the sensitivity of the enzyme to this inhibition slightly differed among species. The stimulation by high $\mathrm{NaCl}$ concentration is a unique feature of human paraoxonase.

The arylesterase activity was lowered by $1 \mathrm{M}$ $\mathrm{NaCl}$ in the rabbit serum from 912.5 (873.0-935.6 U/ml) to $403.5(298-309 \mathrm{U} / \mathrm{ml})$, i.e. by $66.7 \%$ (range: $65.7-67.2 \%, P<0.001$ ) and in the mouse serum from 59.3 (52.6-63.9 $\mathrm{U} / \mathrm{ml})$ to $25.8(25.1-26.6 \mathrm{U} / \mathrm{ml})$, i.e. by $57.5 \%$ (range: $50.0-58.4 \%, P<0.01$ ). It should be noted that the arylesterase activity was markedly more sensitive to inhibition by $\mathrm{NaCl}$ than the paraoxon-hydrolyzing activity in all mammalian species studied.

\section{The effect of other salts and nonelectrolytes on PON1}

To investigate whether the stimulation of human $\mathrm{PON} 1$ by $\mathrm{NaCl}$ is a specific effect of given ions or a nonspecific phenomenon resulting from high osmolality and/or ionic strength of the solution, we studied the effect of other compounds on PON1 activity toward paraoxon (Fig. 5). In this experiment, $1 \mathrm{M} \mathrm{NaCl}$ increased the enzyme activity by $79.9 \%$ (range: 41.0-121.1\%). Potassium chloride caused a comparable increase in PON1 activity (median: $96.7 \%$, range $42.5-315.2 \%)$. In contrast, sodium acetate had no significant effect on the paraoxon-hydrolyzing enzyme. Also sodium lactate did not change the PON1 activity. $\mathrm{NH}_{4} \mathrm{Cl}$ was a less effective activator of PON1 than either $\mathrm{NaCl}$ or $\mathrm{KCl}$. The activity measured in the presence of this salt increased by $54.0 \%$ (range: $2.4-98.5 \%$ ). Sodium nitrite also increased the PON1 activity but only by $32.6 \%(0.3-54.3 \%)$. The effect of sodium nitrate was comparable to sodium nitrite. Sucrose (2 M) did not change the PON1 activity. Addition of $1 \mathrm{M} \mathrm{MgCl}_{2}$ or $1 \mathrm{M}$ $\mathrm{NaH}_{2} \mathrm{PO}_{4}$ caused almost complete inhibition of PON1 activity, most likely due to the displacement of calcium from PON1 molecules by $\mathrm{Mg}^{2+}$ and $\mathrm{Ca}^{2+}$ binding in the solution by $\mathrm{H}_{2} \mathrm{PO}_{4}{ }^{-}$, respectively.

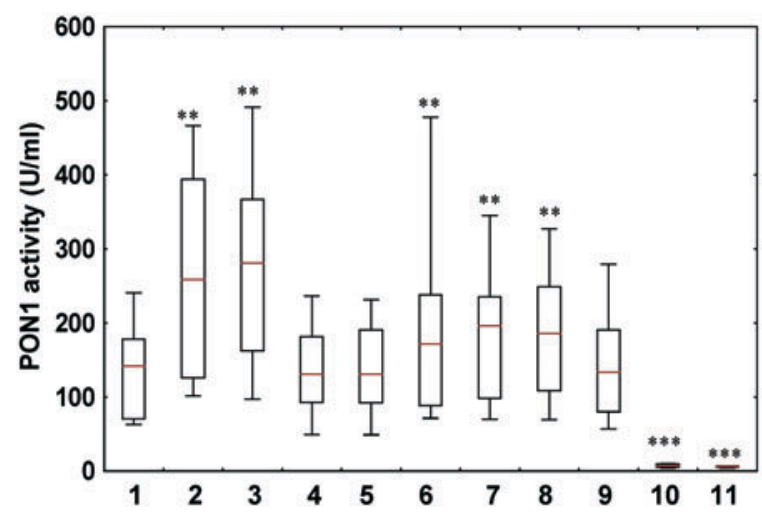

Figure 5. The effect of different compounds on human serum PON1 activity toward paraoxon.

1, control; $2, \mathrm{NaCl} ; 3, \mathrm{KCl} ; 4$, sodium acetate; 5 , sodium lactate; $6, \mathrm{NH}_{4} \mathrm{Cl} ; 7, \mathrm{NaNO}_{2} ; 8, \mathrm{NaNO}_{3} ; 9$, sucrose; 10 , $\mathrm{MgCl}_{2} ; 11, \mathrm{NaH}_{2} \mathrm{PO}_{4}$. Sucrose was added at $2 \mathrm{M}$, other compounds at $1 \mathrm{M}$. ${ }^{* *} P<0.01,{ }^{* * *} P<0.001$ (compared to control by nonparametric Wilcoxon's test).

Human serum AE activity was decreased by $1 \mathrm{M} \mathrm{KCl}$ from $171.9(134.1-207.7 \mathrm{U} / \mathrm{ml})$ to $125.0(90.2-150.7 \mathrm{U} / \mathrm{ml})$, i.e. by $26.5 \%$ (18.6-32.8\%, $P<0.01$ ). Thus, $\mathrm{KCl}$ and $\mathrm{NaCl}$

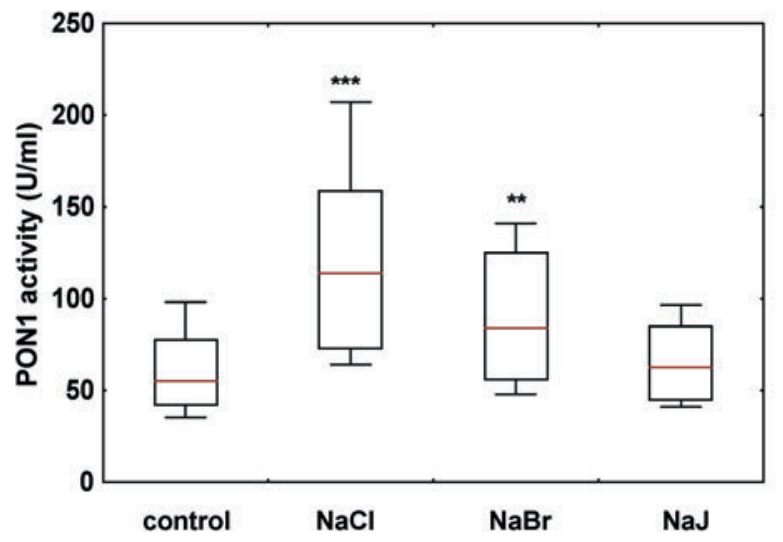

Figure 6. The effect of sodium halides on human serum PON1 activity toward paraoxon.

${ }^{* *} P<0.01,{ }^{* * *} P<0.001$ (compared to control by nonparametric Wilcoxon's test). 
caused a comparable degree of inhibition. Sodium acetate $(1 \mathrm{M})$ decreased the AE activity much more markedly, to 80.7 (64.1-98.3 $\mathrm{U} / \mathrm{ml})$, i.e. by $52.2 \%(51.2-53.5 \%, P<0.001)$. In contrast, $2 \mathrm{M}$ sucrose inhibited human serum $\mathrm{AE}$ to $151.0(115.7-188.3 \mathrm{U} / \mathrm{ml})$, i.e. only by $9.4 \%(8.4-14.2 \%, P<0.05)$.

The paraoxon-hydrolyzing activity of the rat and rabbit sera was inhibited by $1 \mathrm{M} \mathrm{KCl}$ to a similar degree as by $\mathrm{NaCl}$. In contrast, sodium acetate decreased the rat and rabbit PON1 activity by $30-40 \%$. Sucrose ( $2 \mathrm{M}$ ) tended to stimulate PON1 slightly in both these species, but the effect was not significant.

\section{The effect of different halides on human PON1}

The potent stimulation of human serum PON1 by $\mathrm{Cl}^{-}$-containing salts prompted us to compare the effect of different halides (Fig. 6). As can be seen in this figure, $\mathrm{NaBr}$ was a less potent activator of PON1 than $\mathrm{NaCl}$ whereas the effect of $\mathrm{NaJ}$ was non-significant. These data suggest that the stimulation of human PON1 by sodium halides increases with the decreasing atomic mass of the halogene ion. Surprisingly, vigorous spontaneous hydrolysis of paraoxon without addition of serum was observed in the solution containing $1 \mathrm{M} \mathrm{NaF}$. Therefore, it was not possible to measure the enzyme activity in the presence of this salt.

\section{The effect of $\mathrm{NaCl}$ on lactonase activity of human PON1}

Finally, we investigated whether $\mathrm{NaCl}$ affects also the lactonase activity of human PON1. For this purpose, we measured the homogentisic acid lactone- and $\gamma$-decanolactone-hydrolysing activity of human serum. We observed no significant difference between these activities assayed in the absence and in the presence of $1 \mathrm{M} \mathrm{NaCl}$ (homogentisic acid-hydrolyzing activity without $\mathrm{NaCl}$ : median $9.11 \mu \mathrm{mol} / \mathrm{min}$ per $\mathrm{ml}$, range
5.31-18.79 $\mu \mathrm{mol} / \mathrm{min}$ per $\mathrm{ml}$; homogentisic acid-hydrolyzing activity with $1 \mathrm{M} \mathrm{NaCl}$ : median $11.00 \mu \mathrm{mol} / \mathrm{min}$ per $\mathrm{ml}$, range 7.20 $16.34 \mu \mathrm{mol} / \mathrm{min}$ per ml; $\gamma$-decanolactone hydrolyzing activity without $\mathrm{NaCl}$ : median 7.72 $\mu \mathrm{mol} / \mathrm{min}$ per $\mathrm{ml}$, range $4.86-10.20$ $\mu \mathrm{mol} / \mathrm{min}$ per $\mathrm{ml} ; \gamma$-decanolactone-hydrolyzing activity in the presence of $1 \mathrm{M} \mathrm{NaCl}$ : median $7.70 \mu \mathrm{mol} / \mathrm{min}$ per $\mathrm{ml}$, range $4.56-9.72$ $\mu \mathrm{mol} / \mathrm{min}$ per $\mathrm{ml}$ ). Thus, the effect of $\mathrm{NaCl}$ on human PON1 depends on the hydrolyzed substrate and ranges from inhibition (phenyl acetate) through no change (lactones) to stimulation (paraoxon).

\section{DISCUSSION}

The results of this study confirm that the activity of human PON1 toward paraoxon is stimulated by high $\mathrm{NaCl}$ concentration (Eckerson et al., 1983a; 1983b). In contrast, $\mathrm{NaCl}$ reduced the PON1 activity toward phenyl acetate and did not change its lactonase activity. Previous studies (Eckerson et al., 1983a; 1983b) demonstrated that only the $\mathrm{R}$ phenotype (arginine at position 192) was activated by $\mathrm{NaCl}$, whereas the $\mathrm{Q}$ phenotype (glutamine at this position) was not. In the present experiment we observed stimulation of PON1 in all studied individuals. We did not determine the PON1 genotype in our study. The $\mathrm{R}$ and $\mathrm{Q}$ phenotypes can also be discriminated on the basis of the ratio between the enzyme activity toward paraoxon and toward phenyl acetate. However, this requires a larger population to be done reliably (Geldmacher von Mallinckrodt et al., 1983; Juretic et al., 2001). Because we observed a broad range of PON1 activities, we suppose that both phenotypes were represented in the study group. A strong correlation was noted between the baseline activity and the NaCl-stimulated increase in activity, which suggests that the $\mathrm{R}$ phenotype (characterized by higher paraoxon-hydrolyzing activity) was stimulated by $\mathrm{NaCl}$ more than the $\mathrm{Q}$ phenotype. 
PON1 activity is examined in either serum or heparinized plasma (Hasselwander et al., 1999). We have demonstrated that the PON1 activity is slightly lower in heparinized plasma than in serum. However, human PON1 is stimulated by $\mathrm{NaCl}$ in both serum and plasma, and a very strong correlation exists between the PON1 activities in both fluids in the absence as well as in the presence of $\mathrm{NaCl}$. Thus, we suggest that either serum or heparinized plasma may be used for the enzyme assay.

In contrast to humans, PON1 was suppressed by $\mathrm{NaCl}$ in other mammalian species studied. It is unclear at present what determines this specific effect of $\mathrm{NaCl}$ on the human enzyme. The amino-acid sequence of rat, rabbit and mouse PON1 demonstrates 79.9\%, 85.3\% and 82.3\% homology with human PON1, respectively. Even small structural differences can affect the paraoxon-hydrolyzing activity and the effect of $\mathrm{NaCl}$, as evidenced by the higher sensitivity to the NaCl-induced stimulation of human $\mathrm{R}$ in comparison with the $\mathrm{Q}$ isoenzyme differing in only one residue (Eckerson et al., 1983a). Apart from the structure of paraoxonase itself, species-specific composition of other HDL components may be responsible for this unique feature of the human enzyme, because binding to phospholipids and apolipoprotein AI is essential to maintain PON1 activity (Sorenson et al., 1999).

The results of studies comparing the effect of different salts and sucrose on human PON1 (Fig. 5) indicate that: 1) neither salts of organic anions nor nonelectrolytes had any significant effect on human PON1, thus the stimulation by $\mathrm{NaCl}$ does not result from either osmolality or ionic strength of the solution; 2) the effect of $\mathrm{NaCl}$ is not specific for this salt, however, among inorganic salts chlorides seem to be the most effective activators, although the accompanying cation also has some significance (weaker effect of $\mathrm{NH}_{4} \mathrm{Cl}$ vs $\mathrm{NaCl}$ and $\mathrm{KCl}$ ).

The $\mathrm{AE}$ activity was equipotently inhibited by $\mathrm{NaCl}$ and $\mathrm{KCl}$. Sodium acetate caused more marked inhibition whereas sucrose only slightly decreased human AE activity. These results indicate that high ionic strength of the solution, not high osmolality, is responsible for $\mathrm{AE}$ inhibition by high salt concentration. The difference between the effects of $\mathrm{NaCl}$ or $\mathrm{KCl}$ and sodium acetate suggests the possibility that $\mathrm{Cl}^{-}$has also the ability to stimulate the enzyme activity toward phenyl acetate, however, this is abolished by the nonspecific inhibitory effect exerted for by high ionic strength of the solution. In contrast, the activity toward paraoxon is less sensitive to the effect of ionic strength because it is unaltered or even slightly increased by other salts, which results in marked stimulation of this activity by $\mathrm{Cl}^{-}$. This hypothesis, however, requires confirmation by further studies.

The physiologic significance of PON1 activation by $\mathrm{NaCl}$ is unclear. The salt concentration required to cause significant changes in the enzyme activity is far above that observed in vivo. In addition, the paraoxon-hydrolysing activity does not necessarily correlate with the antioxidant properties of paraoxonase. For example, genetic polymorphism of human PON1 has opposite effects on paraoxon hydrolysis and the antioxidant properties. The $R$ isoenzyme has a higher paraoxon-hydrolysing activity than the $\mathrm{Q}$ isoenzyme, but is less effective in preventing lipoprotein oxidation (Mackness et al., 1997; 1998). The antioxidative PON1 activity is dependent on a different active site than its esterase activity. Inhibition of LDL oxidation by PON1 requires free $\mathrm{SH}$ groups, and is $\mathrm{Ca}^{2+}$-independent, whereas the esterase activity requires $\mathrm{Ca}^{2+}$ but not free SH groups (Aviram et al., 1998a). To our knowledge, the effect of $\mathrm{NaCl}$ on the antioxidant activity of PON1 has not been studied so far. This would, however, require purification of paraoxonase because other components of HDL, such as platelet-activating factor acetylhydrolase (PAF-AH) and lecithin : cholesterol acyltransferase (LCAT) also have antioxidant properties (Mackness \& Durrington, 1995). Isolation of PON1 from its natural 
microenvironment could, on the other hand, modify the effect of salts. The lactonase activity which is suggested to better correlate with the physiologic enzyme function (Billecke et al., 2000) did not change in the presence of the $\mathrm{NaCl}$ in this study. Thus, the physiologic significance of the $\mathrm{NaCl}$-induced stimulation is unclear.

However, some studies suggest that the basal and NaCl-stimulated PON1 activities are differentially affected in pathologic conditions. For example, Schiavon et al. (1996) found that the basal but not the $\mathrm{NaCl}$-activated enzyme activity is reduced in hemodialyzed patients. We have recently found (unpublished observation) that the paraoxon-hydrolyzing activity of human serum decreases following surgical trauma if measured in the absence but not in the presence of $\mathrm{NaCl}$. These data suggest that under some conditions, the basal PON1 activity is more sensitive to modifying factors than the $\mathrm{NaCl}$-stimulated activity. It would be interesting to recognize factors which determine the enzyme activity in the absence as well as in the presence of $\mathrm{NaCl}$. It is likely that the changes of activity observed under both conditions indicate more profound abnormalities than changes of only the basal but not the stimulated activity. Further studies addressing the PON1 activity under different physiologic and pathologic conditions in the absence as well as in the presence of $\mathrm{NaCl}$ are needed to verify this possibility.

\section{R E F E R E N C E S}

Aviram M, Billecke S, Sorenson R, Bisgaier C, Newton R, Rosenblat M, Erogul J, Hsu C, Dunlop C, La Du B. (1998a) Paraoxonase active site required for protection against LDL oxidation involves its free sulfhydryl group and is different from that required for its arylesterase/paraoxonase activities: selective action of human paraoxonase allozymes $\mathrm{Q}$ and R. Arterioscler Thromb Vasc Biol.; 18: 1617-24.
Aviram M, Rosenblat M, Bisgaier CL, Newton RS, Primo-Parmo SL, La Du BN. (1998b) Paraoxonase inhibits high-density lipoprotein oxidation and preserves its functions. $J$ Clin Invest.; 101: 1581-90.

Aviram M, Hardak E, Vaya J, Mahmood S, Milo S, Hoffman A, Billicke S, Draganov D, Rosenblat M. (2000) Human serum paraoxonase (PON) Q and R selectively decrease lipid peroxides in human coronary and carotid atherosclerotic lesions: PON1 esterase and peroxidase-like activities. $\mathrm{Circu}$ lation.; 101: 2510-7.

Ayub A, Mackness MI, Arrol S, Mackness B, Patel J, Durrington PM. (1999) Serum paraoxonase after myocardial infarction. Arterioscler Thromb Vasc Biol.; 19: 330-5.

Billecke S, Draganov D, Counsell R, Stetson P, Watson C, Hsu C, La Du BN. (2000) Human serum paraoxonase (PON1) isozymes $\mathrm{Q}$ and $\mathrm{R}$ hydrolyze lactones and cyclic carbonate esters. Drug Metab Dispos.; 28: 1335-42.

Draganov DI, Stetson PL, Watson CE, Billecke SS, La Du BN. (2000) Rabbit serum paraoxonase-3 (PON3) is a high density lipoprotein-associated lactonase and protects low density lipoprotein against oxidation. J Biol Chem.; 275: 33435-42.

Durrington PN, Mackness B, Mackness MI. (2001) Paraoxonase and atherosclerosis. Arterioscler Thromb Vasc Biol.; 21: 473-80.

Eckerson HW, Wyte CM, La Du BN. (1983a) The human serum paraoxonase/arylesterase polymorphism. Am J Hum Genet.; 35: 1126-8.

Eckerson HW, Ramson J, Wyte C, La Du BN. (1983b) The human paraoxonase polymorphism: identification of phenotypes by their response to salts. Am J Hum Genet.; 35: 214-7.

Geldmacher von Mallinckrodt M, Diepgen TL, Duhme C, Hommel G. (1983) A study of the polymorphism and ethnic distribution difference of human serum paraoxonase. Am J Phys Anthropol.; 62: 235-41.

Hasselwander O, McEneny J, McMaster D, Fogarty DG, Nicholls DP, Maxwell AP, Young 
IS. (1999) HDL composition and HDL antioxidant capacity in patients on regular hemodialysis. Atherosclerosis.; 143: 125-33.

Jakubowski H. (2000) Calcium-dependent human serum homocysteine thiolactone hydrolase. J Biol Chem.; 275: 3957-62.

Juretic D, Tadijanovic M, Rekic B, SimeonRudolf V, Reiner E, Baricic M. (2001) Serum paraoxonase activities in hemodialyzed uremic patients: cohort study. Croat Med J.; 42: $146-50$.

La Du BN, Adkins S, Kuo CL, Lipsig D. (1993) Studies on human serum paraoxonase/arylesterase. Chem Biol Interact.; 87: 25-34.

Mackness ML, Durrington PN. (1995) HDL, its enzymes and its potential to influence lipid peroxidation. Atherosclerosis.; 115: 243-53.

Mackness ML, Arrol S, Durrington PN. (1991) Paraoxonase prevents accumulation of lipoperoxides in low-density lipoproteins. FEBS Lett.; 286: 152-4.

Mackness MI, Arrol S, Abbott C, Durrington PN. (1993) Protection of low-density lipoprotein against oxidative modification by high-density lipoprotein associated paraoxonase. Atherosclerosis.; 104: 129-35.

Mackness ML, Mackness B, Durrington PN, Connelly PW, Hegele RA. (1996) Paraoxonase: biochemistry, genetics and relationship to plasma lipoproteins. Curr Opin Lipidol.; 7: 69- 76.

Mackness ML, Arrol S, Mackness B, Durrington PN. (1997) The alloenzymes of paraoxonase determine the effectiveness of high-density lipoproteins in protecting low density lipoprotein against lipid-peroxidation. Lancet.; 349: 851-2.

Mackness B, Mackness ML, Arrol S, Turkie W, Durrington PN. (1998) Effect of the human paraoxonase 55 and 192 genetic polymorphisms on the protection by high density lipoprotein against low density lipoprotein oxidative modification. FEBS Lett.; 423: 57-60.

Ng CJ, Wadleigh DJ, Gangopadhyay A, Hama S, Grijalva V, Navab M, Fogelman AM, Reddy ST. (2001) Paraoxonase-2 is a ubiquitously expressed protein with antioxidant properties and is capable of preventing cell-mediated oxidative modification of low density lipoprotein. J Biol Chem.; 276: 44444-9.

Reddy ST, Wadleigh DJ, Grijalva V, Ng C, Hama S, Gangopadhyay A, Shih DM, Lusis AJ, Navab M, Fogelman AM. (2001) Human paraoxonase-3 is an HDL-associated enzyme with biological activity similar to paraoxonase-1 protein but is not regulated by oxidized lipids. Arterioscler Thromb Vasc Biol.; 21: $542-7$.

Rodrigo L, Mackness B, Durrington PN, Hernandez A, Mackness MI. (2001) Hydrolysis of platelet-activating factor by human serum paraoxonase. Biochem J.; 354: 1-7.

Schiavon R, De Fanti E, Giavarina D, Biasioli S, Cavalcanto G, Guidi G. (1996) Serum paraoxonase activity is decreased in uremic patients. Clin Chim Acta.; 247: 71-80.

Sorenson RC, Bisgaier CL, Aviram M, Hsu C, Billecke S, La Du BN. (1999) Human serum paraoxonase/arylesterase's retained hydrophobic N-terminal leader sequence associates with HDLs by binding phospholipids. Arterioscler Thromb Vasc Biol.; 19: 2214-25.

Watson AD, Berliner JA, Hama SY, La Du BN, Faull KF, Fogelman AM, Navab M. (1995) Protective effect of high density lipoprotein associated paraoxonase. Inhibition of the biological activity of minimally oxidized low density lipoprotein. J Clin Invest.; 96: 2882-91. 